\title{
Impacts of Saltwater Intrusion on the Fish Assemblage in the Middle Part of Shatt Al-Arab River, Iraq
}

\author{
Abdul-Razak M. Mohamed ${ }^{1 *}$ and Entisar K. Hameed ${ }^{2}$ \\ ${ }^{1}$ Department of Fisheries and Marine Resources, College of Agriculture \\ University of Basrah, Iraq \\ ${ }^{2}$ Department of Marine Vertebrates, Marine Science Centre \\ Basrah University, Iraq \\ *Corresponding author's email: abdul19532001 [AT] yahoo.com
}

\begin{abstract}
In 2018, a serious changes in the salinity of the Shatt Al-Arab river, as salinity intrusion progressed further to upper reaches of the river due to sharply decline in river flow. Therefore, the fish assemblage structure in the middle of the river, from Sindbad and Abu Al-Khasibs was assessed during the period from January to December 2018. Fish were sampled by gill nets, cast net and electro-fishing from both sites. Salinity fluctuated from 2.0\% (January) in both sites to 16.2 and $25.0 \%$ during August in both sites, respectively. 35 and 44 fish species were collected from both sites, respectively, these included 18 marine species in first site and 28 marine species in second site. Poecilia latipinna, Tenualosa ilisha and Oreochromis aureus were the dominant species in first site, whereas $O$. aureus, Carassius auratus and P. latipinna in second site. The index of species richness, diversity and evenness each showed a consistent seasonal pattern in both sites. The highest value of Bray-Curtis similarity index of fish species between both sites was noted during the period of low salinity. Findings indicate that the salinity values and the percentages of marine and occasional species were considerably higher than that documented in the previous studies on this part of the river.
\end{abstract}

Keywords-- Salinity intrusion, fish assemblage, biodiversity indices, Shatt Al-Arab River, Iraq

\section{INTRODUCTION}

Saltwater intrusion is the flow of seawater into freshwater coastal rivers due to natural processes or human activities. It is one of the most significant global challenges for coastal water resource managers, industries, and agriculture.The distance of the salinity intrusion is controlled by river flow, sea level change, tidal range, geomorphological features of the estuary, changes in the drainage basin, water intakes for urban water supply and others [1,2]. Salinity intrusion is a natural phenomenon subject to many factors such as the flow of the river which is the key to controlling the incursion of salt [3].

Saltwater intrusion is a major concern commonly found in estuaries around the world, therefore, several authors have been discussed the environmental impacts of saltwater intrusion in different estuaries, Such as [4-9] or on fish assemblages that inhabit coastal rivers, Such as [10-13].

Like many other parts of the world, Iraq has also suffered from the impacts of water shortages due to the decline in the discharge of water from its neighboring countries, as a result of several hydrological projects constructed on the Tigris and the Euphrates rivers in these countries [14]. Therefore, Shatt Al-Arab river has suffered during the past years from massive regression in water quality and quantitative related to the decline in rates of discharge from these rivers [15] as well as Iran's conversion of the Karun River to its territory [16]. This serious reduction in freshwater inflows to Shatt Al-Arab river permitted the saltwater to intrude upstream of the river and this has been discussed by several authors [17-19, 3, 20]. Also, several studies have focused on fish assemblage structure in different parts of the Shatt Al-Arab River under these circumstances [21, 22, 23, 24].

In 2018, a serious changes in the salinity of the Shatt Al-Arab river, as salinity intrusion progressed further to upper reaches of the river that had never been reached before and salinity level continued rising substantially for the most of the months, which affected extremely the water supply and all uses in the province of Basrah during this year. Therefore, the primary aim of this study is to evaluate the fish assemblage in the middle of the Shatt Al-Arab river under this circumstance. 


\section{MATERIALS AND METHOD}

The Tigris and Euphrates rivers originate in Turkey and form the Shatt Al-Arab river at their confluence near the city of Qurna, southern Iraq. The other two tributaries, Karkheh and Karun, originate in Iran. The Karkheh is connected with the Shatt al Arab river through a system of marshes, while the Karun discharges into the Shatt al Arab river at approximately $87 \mathrm{~km}$ from the mouth. The southern part of the river constitutes the border between Iran and Iraq until it discharges into the Arabian Gulf (Fig. 1), with a total length of $204 \mathrm{~km}$, and varies in width from $250 \mathrm{~m}$ at Al-Qurna to more than 1,500 $\mathrm{m}$ at the estuary. Its depth fluctuates from 9m at Al-Dair, 10m in Abu Al-Khasib to 11m in Fao [25]. Formerly, several tributaries join the Shatt Al-Arab river during its course, most importantly the Karkheh and the Karun rivers. Nowadays, the flow of Shatt Al-Arab is much smaller than before because of massive dam projects in Turkey [26].

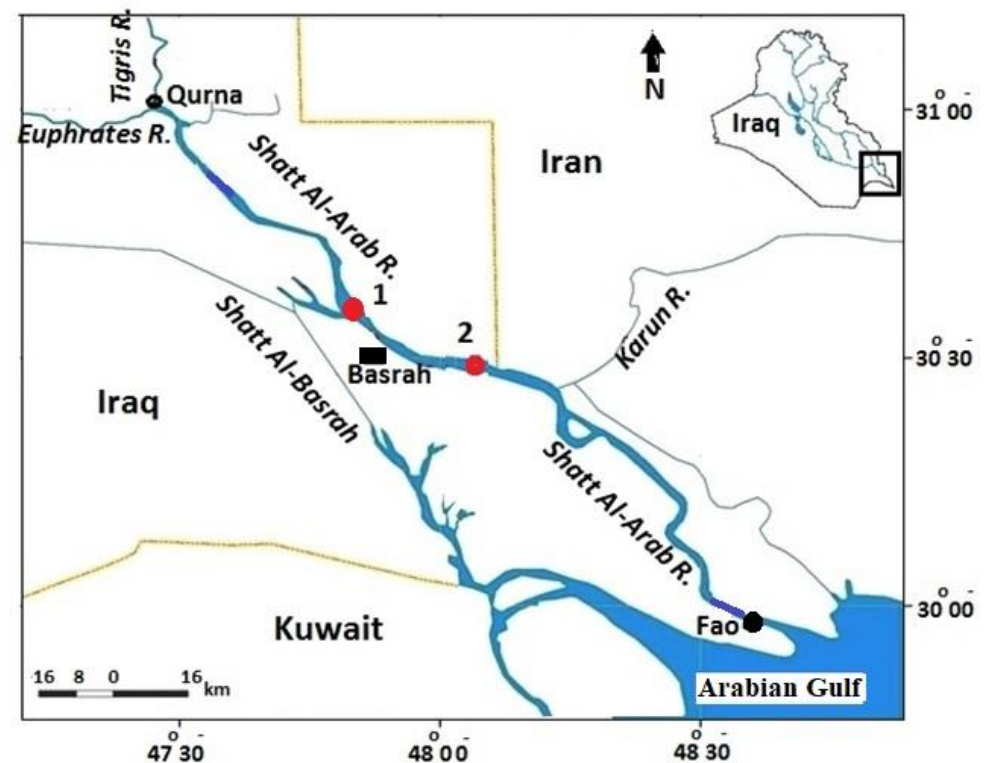

Fig. 1. Map of Shatt Al-Arab with locations of study sites.

The study was conducted on the middle part of the river and the observations were done monthly at two sites in this part (Fig. 1) from January to December 2018. Sindbad site (Sindbad) is located north Sindbad Island (30 $58^{\prime} 16^{\prime \prime} \mathrm{N}, 47^{\circ}$ $\left.77^{\prime} 11^{\prime \prime} \mathrm{E}\right)$, whereas Abu Al-Khasib site (Al-Khasib) is sited south of Abu Al-Khasib district ( $\left.30^{\circ} 46^{\prime} 37^{\prime \prime} \mathrm{N}, 47^{\circ} 77^{\prime} 11^{\prime \prime} \mathrm{E}\right)$ and this site clearly affected by the tidal current of the Arabian Gulf. The predominant vegetation on the banks of both sites were Phragmites australis, Vallisneria spiralis, Typha domingensis and Ceratophyllum demersum. Both sites are suitable for fishing operations and therefore many fishermen practice fishing here using different fishing gears.

Both sites had been sampled using gill nets (200-500 m length with $25 \times 25 \mathrm{~mm}$ mesh size), cast net ( 8 m diameter with $15 \times 15 \mathrm{~mm}$ mesh size) and electro-fishing by generator engine (provides 500V and 10A). Fish were counted and classified to species following [27-30].

In addition, water temperature $\left({ }^{\circ} \mathrm{C}\right)$ and salinity $(\%)$ in each site were measured using YSI portable instrument model 556 MPS. The monthly rate of discharge in the upstream of the Shatt Al-Arab River during 2018 was obtained from Water Resources Directorate in Basrah. Information on structure of fish assemblage was extracted by using different univariate indices.

The relative abundance was calculated from the equation $n_{i} / N \times 100$ [31], where $n_{i}$ is the number of individuals of ' $i^{t h}$ ' species and $N=\Sigma n_{i}$. Shannon's diversity index $\left(H^{\prime}\right)$ was obtained by the following equation $H^{\prime}=-\Sigma p_{i} \ln p_{i}$ [32], where $P_{i}=$ $n_{i} / N ; n_{i}$ is the number of individuals of 'ith' species and $N=\Sigma n_{i}$. Margalef's index $(D)$ was used as a simple measure of species richness [33] using the equation $D=(S-1) / \ln N$, where $S$ is the number of species, $N$ is the total number of individuals. For calculating the evenness of species, the Pielou's Evenness Index ( $J$ ) was used [34] as $J=H^{\prime} / \ln S$, where $H^{\prime}$ is Shannon-Weaver diversity index and $S$ is total number of species in the sample. The Bray-Curtis similarity index of fish species between both sites was calculated according to equation of Bray-Curtis [35]. Fish species divided into categories according to their occurrence in the monthly samples following Tyler [36]. Data were statistically analysed by using Microsoft Office Excel 2010. 


\section{RESULTS}

For each study site, the monthly changes in the values of water temperatures and salinity are presented in Figure 2. Water temperature in Sindbad varied from $16^{\circ} \mathrm{C}$ in January to $33^{\circ} \mathrm{C}$ in August, while in $\mathrm{Abu} \mathrm{Al-Khasib} \mathrm{ranged} \mathrm{from} 16^{\circ} \mathrm{C}$ in December to $35^{\circ} \mathrm{C}$ in August. Water temperature was not significantly different among sites $(t=0.035, \mathrm{p} \leq 0.05)$. Salinity in Sindbad fluctuated from 2.0\%o in January to 16.2\%o in August, whereas in Abu Al-Khasib changed from 2.0\%o in January to $25.0 \%$ in August. Despite the difference between two sites was not statistically significant $(t=1.311, \mathrm{p} \leq 0.05)$, Sindbad has lower salinity than Abu Al-Khasib, and the salinity exhibited unexpectedly increasing from August to October in both sites.

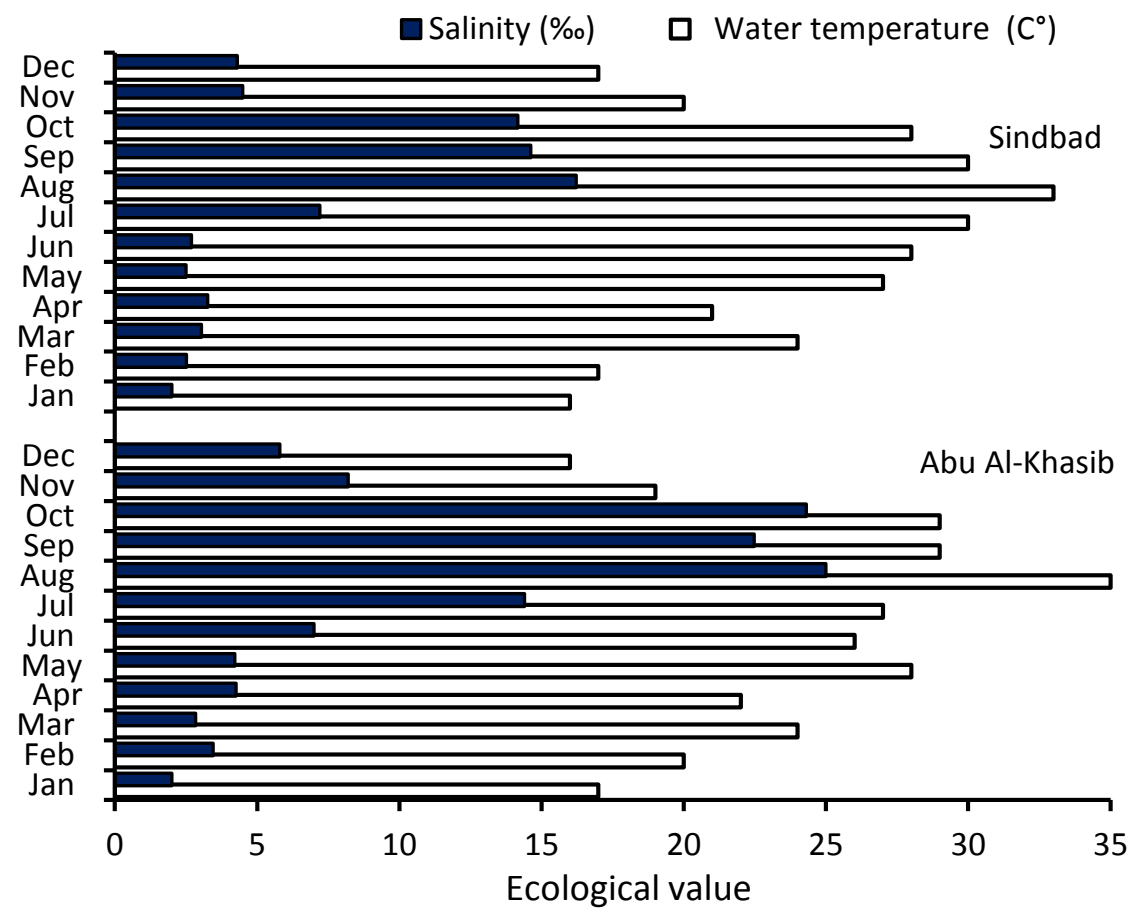

Figure 2: Monthly variations in water temperature and salinity in both sites

As many as 35 species of bony fish belonging to 15 families were recorded during the present investigation in Sindbad and 44 species belonging to 22 families in Abu Al-Khasib (Table 1). These included eight species from each of native and exotic species which recorded in each site, whereas 18 marine species were caught in Sindbad and 28 species in Abu AlKhasib. The best represented family in both site was Cyprinidae with seven species, followed by Mugilidae (4 species). Engraulidae, Sillaginidae, Cichlidae and Soleidae have three species each. Other families each representing by two or single species. Sciaenidae, Ariidae, Belonidae, Soleidae, Triacanthidae, and Cynoglossidae were appeared at Abu AlKhasib only.

Monthly fluctuations in the number and individuals of the species in both sites are shown in Figure 3 . The number of species in Sindbad ranged from 7 in January to 22 in May, while in Abu Al-Khasib from 5 in February to 33 in December. Generally, the number of species started to increase from February to May. The highest proportion of individuals in Sindbad was $15.6 \%$ of the total individuals showed in June and the lowest proportion was $5.3 \%$ caught in February, while in Abu Al-Khasib, the highest one was 16.9\% of the total individuals in May and the lowest one was 3.0\% found in February. 
Table 1: Fish species caught from both sites from the Shatt Al-Arab (N= Native, $M=$ Marine, E= Exotic)

\begin{tabular}{|c|c|c|c|c|c|}
\hline Family & Species & Site & Family & Species & te \\
\hline Cyprinidae & Carassius auratus $(\mathrm{E})$ & $1 \& 2$ & Belonidae & Strongylura strongylura $(\mathrm{M})$ & 2 \\
\hline$=$ & Leuciscus vorax $(\mathrm{N})$ & $1 \& 2$ & Cichlidae & Oreochromis aureus $(\mathrm{E})$ & $1 \& 2$ \\
\hline$=$ & Carasobarbus luteus $(\mathrm{N})$ & $1 \& 2$ & $=$ & Oreochromis niloticus $(\mathrm{E})$ & $1 \& 2$ \\
\hline$=$ & Hemiculter leucisculus (E) & $1 \& 2$ & $=$ & Coptodon zillii (E) & $1 \& 2$ \\
\hline$=$ & Alburnus mossulensis (N) & $1 \& 2$ & Gobiidae & Boleophthalmus dussumieri (M) & $1 \& 2$ \\
\hline$=$ & Acanthobrama marmid $(\mathrm{N})$ & $1 \& 2$ & $=$ & Bathygobius fuscus (M) & $1 \& 2$ \\
\hline$=$ & Cyprinus carpio (E) & $1 \& 2$ & Soleidae & Solea 580longate (M) & 2 \\
\hline Sciaenidae & Otolithes ruber $(\mathrm{M})$ & 2 & $=$ & Solea stanalandi $(\mathrm{M})$ & 2 \\
\hline Mugilidae & Planiliza $a b u(\mathrm{~N})$ & $1 \& 2$ & $=$ & Brachirus orientalis $(\mathrm{M})$ & $1 \& 2$ \\
\hline$=$ & Planiliza subviridis $(\mathrm{M})$ & $1 \& 2$ & Platycephalidae & Platycephalus indicus (M) & 2 \\
\hline$=$ & Planiliza carinata $(\mathrm{M})$ & $1 \& 2$ & Poeciliidae & Poecilia latipinna (E) & $1 \& 2$ \\
\hline$=$ & Planiliza klunzingeri (M) & $1 \& 2$ & Triacanthidae & Triacanthus biaculeatus (M) & 2 \\
\hline Sparidae & Acanthopagrus arabicus $(\mathrm{M})$ & $1 \& 2$ & Cynoglossidae & Cynoglossus arel (M) & 2 \\
\hline Engraulidae & Thryssa whiteheadi (M) & $1 \& 2$ & $=$ & Cynoglossus kopsii (M) & 2 \\
\hline$=$ & Thryssa vitrirostris (M) & $1 \& 2$ & Leiognathidae & Photopectoralis bindus (M) & $1 \& 2$ \\
\hline$=$ & Thryssa dussumieri (M) & $1 \& 2$ & Scatophagidae & Scatophagus argus (M) & $1 \& 2$ \\
\hline Sillaginidae & Sillago arabica $(\mathrm{M})$ & $1 \& 2$ & Hemiramphidae & Hyporhamphus limbatus (M) & $1 \& 2$ \\
\hline$=$ & Sillago sihama (M) & $1 \& 2$ & Siluridae & Silurus triostegus $(\mathrm{N})$ & $1 \& 2$ \\
\hline$=$ & Sillago attenuata (M) & $1 \& 2$ & Bagridae & Mystus pelusius (N) & $1 \& 2$ \\
\hline Ariidae & Plicofollis dussumieri (M) & 2 & Cyprinodontidae & Aphanius dispar $(\mathrm{N})$ & $1 \& 2$ \\
\hline$=$ & Plicofollis layavdi (M) & 2 & $=$ & Gambusia holbrooki (E) & $1 \& 2$ \\
\hline \multirow[t]{2}{*}{ Clupeidae } & Tenualosa ilisha $(\mathrm{M})$ & $1 \& 2$ & & & \\
\hline & Nematalosa nasus (M) & $1 \& 2$ & & & \\
\hline
\end{tabular}

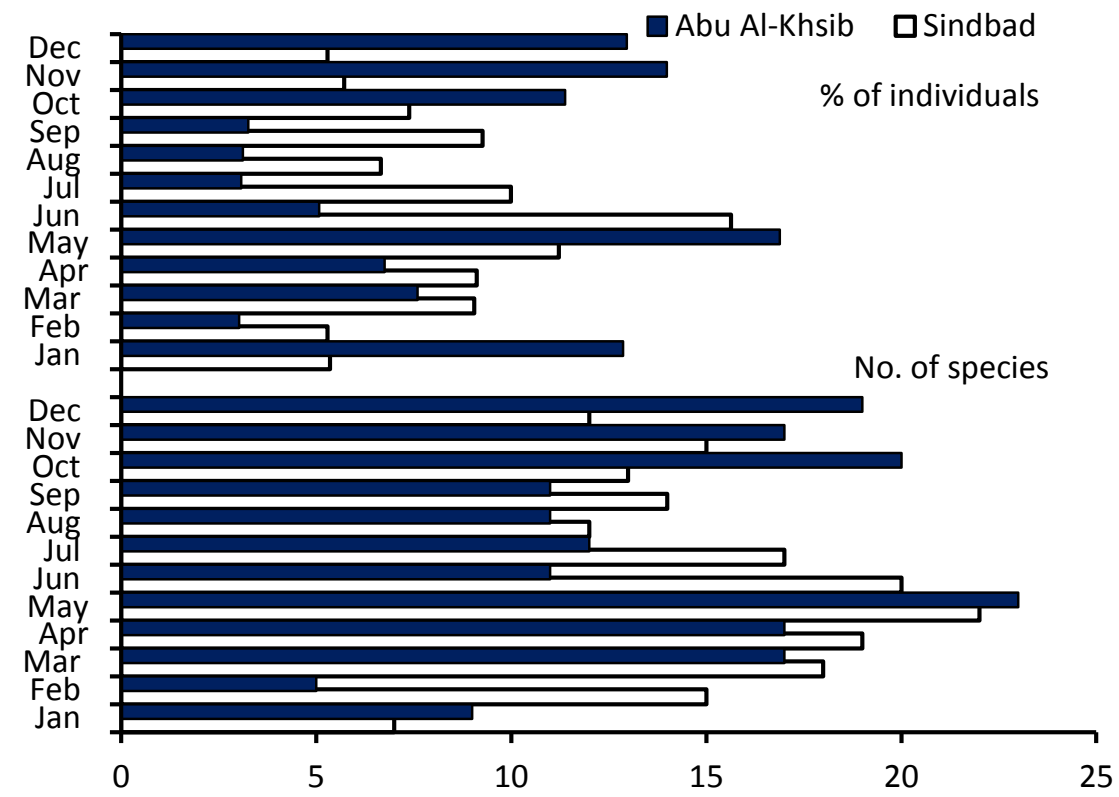

Figure 3: Monthly variations in the number of species and individuals in both sites

The number of native species in Sindbad varied from one species in January, September and October to 5 species in May and July (Fig. 4), and constituted $23.5 \%$ of the total number of species, whereas the marine species consisted $52.9 \%$ and fluctuated from two species in January to 11 species in April. The exotic species in this site formed $23.5 \%$ and changed from three species in August to eight species in June. There was more marine species represented in Abu Al-Khasib constituted $63.6 \%$ of the total number of species and ranged from one species in January and February to 14 species in October and December, while the native species formed $18.2 \%$ and varied from one species in March, June, July and 
September to four species in May (Fig. 4). The exotic species in this site comprised $18.2 \%$ and fluctuated from four species in February, September and October to seven species in March and May.

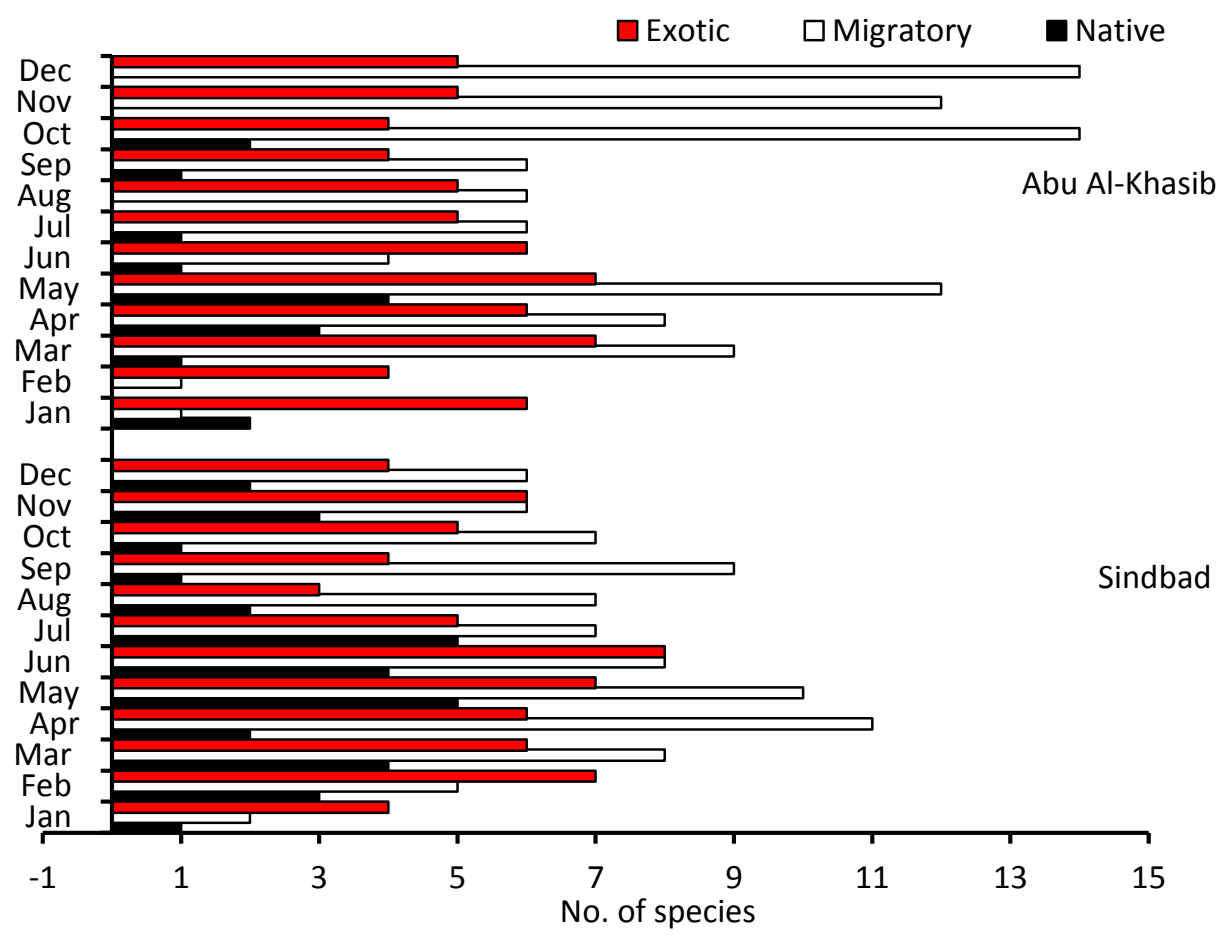

Figure 4: Monthly variations in the number of native, marine and exotic species in both sites

The relative abundances of fish individuals species which constituted more than $1.0 \%$ of the catch were considered to be importance in both sites of the river are presented in Table 2. The fish assemblage in Sindbad was dominated by $P$. latipinna composed of $13.8 \%$ of the total and varied from 3.3\% in August to 27.4\% February. T ilisha was constituted $11.8 \%$ and the relative abundance ranged from $5.2 \%$ in December to $19.2 \%$ in February. O. aureus comprised $11.7 \%$ of the total, it fluctuated from $5.1 \%$ in November to $31.1 \%$ in January. O. aureus dominated the fish assemblage in Abu AlKhasib comprised $12.5 \%$ of the total, it ranged from $1.5 \%$ in November to $34.8 \%$ in May. C. auratus instituted $12.3 \%$ and varied from $1.0 \%$ in November to $56.0 \%$ in February, followed by P. latipinna which constituted $12.1 \%$ of the total and ranged from $0.4 \%$ in October to $33.8 \%$ June.

Shannon-Wiener diversity $(H)$, Margalef richness $(D)$ and Pielou's evenness $(J)$ indices fluctuated between months (Fig. 5).The diversity index varied from 1.51 in January to 2.90 in September, with overall value 2.37 in Sindbad, while the richness index changed from 1.39 in January to 4.16 in May, with overall value 2.95, whereas the evenness index varied from 0.78 in January to 1.10 in September, with overall value 0.88 . In the other hand, the minimum value of diversity index in Abu Al-Khasib was 1.50 recorded in July and maximum value was recorded 2.20 recorded in October and November, with overall value 1.96, while the richness index fluctuated from 2.40 in January to 3.73 in May, with overall value 2.94, and evenness index had its highest value in September (0.90) and the lowest in May (0.65), with overall value 0.72. In general, the values of ecological indices were higher during spring months than other months.

The resident species in Sindbad formed $32.4 \%$ of the total number of species, included P. latipinna, T. ilisha, O. aureus, T. whiteheadi, C. zillii, T. vitriastris, B. fuscus, H. limbatus, A. mossulensis, P. bindus and H. leucisculus. The seasonal species in this site comprised $17.6 \%$ of the total number of species involved P. subviridis, P. abu, O. niloticus, A. marmid, $P$. klunzingeri and C. auratus. The rest of the species in Sindbad which formed 50.0\% of the total number of species, were considered as occasional species. Whereas, the resident species in Abu Al-Kasib site formed $18.2 \%$ of the total number of species, included $O$. aureus, $C$. auratus, $P$. latipinna, T. whiteheadi, $O$. niloticus, $C$. zillii, $P$. subviridis and T. ilisha. The seasonal species in this site comprised $6.8 \%$ of the total number of species involved $P$. bindus, $T$. vitriastris and B. fuscus. The rest of the species in Abu Al-Khasib which formed $75.0 \%$ of the total number of species, were considered as occasional species. 
Table 2: Monthly variations in relative abundance fish species which represented more than $1.0 \%$ of the catch from both sites

\begin{tabular}{|c|c|c|c|c|c|c|c|c|c|c|c|c|c|}
\hline Species & Jan & Feb & Mar & Apr & May & Jun & Jul & Aug & Sep & Oct & Nov & Dec & Total \\
\hline \multicolumn{14}{|l|}{ Sindbad } \\
\hline$\overline{P . \text { latipinna }}$ & 17.6 & 27.4 & 23.2 & 8.7 & 18.1 & 14.4 & 10.9 & 3.3 & 10.9 & 6.9 & 8.9 & 16.4 & 13.8 \\
\hline T. ilisha & 6.8 & 19.2 & 12.8 & 11.9 & 5.2 & 10.6 & 17.4 & 16.3 & 12.5 & 13.7 & 11.4 & 5.5 & 11.8 \\
\hline O. aureus & 31.1 & 9.6 & 6.4 & 13.5 & 8.4 & 8.8 & 15.9 & 14.1 & 7.8 & 17.6 & 5.1 & 11.0 & 11.7 \\
\hline T. whiteheadi & - & - & 5.6 & 10.3 & 8.4 & 2.8 & 12.3 & 16.3 & 17.2 & 15.7 & 13.9 & 21.9 & 9.9 \\
\hline C. zillii & 36.5 & 13.7 & 4.0 & 7.1 & 6.5 & 8.8 & 5.1 & 7.6 & 6.3 & 6.9 & 5.1 & - & 8.2 \\
\hline T. vitriastris & & - & 8.8 & 10.3 & 5.2 & 5.1 & 4.4 & 10.9 & 14.8 & 9.8 & 13.9 & 13.7 & 7.9 \\
\hline C. auratus & 2.7 & 6.9 & 11.2 & 9.5 & 12.3 & 11.1 & - & - & - & - & 11.4 & 8.2 & 6.6 \\
\hline B. fuscus & 2.7 & 5.5 & & 4.8 & 5.2 & 8.3 & 5.1 & 5.4 & 6.4 & 2.9 & 5.1 & 1.4 & 4.8 \\
\hline H. limbatus & - & - & 2.4 & 6.4 & 6.5 & 5.6 & 2.9 & 4.4 & 5.5 & & 5.1 & 2.7 & 3.9 \\
\hline A. mossulensis & 2.7 & 1.4 & 5.6 & 0.8 & 0.7 & 4.2 & 5.8 & - & - & 2.0 & 5.1 & 8.2 & 3.0 \\
\hline P. subviridis & - & 1.4 & - & 7.1 & - & - & 2.2 & 9.8 & 6.3 & 10.8 & - & - & 3.0 \\
\hline P. $a b u$ & - & 1.4 & - & - & 5.2 & 4.6 & 7.3 & 3.3 & 1.6 & - & 2.5 & 5.5 & 2.9 \\
\hline P. bindus & - & 2.7 & - & 0.8 & & 1.4 & 2.9 & 6.5 & 5.5 & 9.8 & 3.8 & 1.4 & 2.7 \\
\hline O. niloticus & - & 2.7 & 7.2 & 0.8 & & 3.2 & - & - & - & 1.0 & 3.8 & & 1.7 \\
\hline H. leucisculus & - & 2.7 & 2.4 & 0.8 & 2.6 & 1.4 & 2.2 & - & - & 1.0 & 2.5 & 4.1 & 1.5 \\
\hline C. carpio & - & 2.7 & - & - & 4.5 & 3.7 & - & - & - & - & - & - & 1.2 \\
\hline A. marmid & - & - & 1.6 & 2.4 & 1.94 & & 2.2 & 2.2 & - & - & 2.5 & - & 1.1 \\
\hline \multicolumn{14}{|l|}{ Abu Al-Khasib } \\
\hline O. aureus & 5.8 & 3.7 & 16.6 & 28.3 & 34.8 & 1.5 & 4.6 & 3.0 & 17.1 & 8.6 & 2.0 & 3.3 & 12.5 \\
\hline C. auratus & 37.3 & 56.0 & 16.6 & 10.3 & 6.4 & 33.8 & 1.5 & 3.0 & & & 1.0 & 2.2 & 12.3 \\
\hline P. latipinna & 13.41 & 26.6 & 18.4 & 16.6 & 8.3 & 33.8 & 9.1 & 14.9 & 11.4 & 0.4 & 15.3 & 5.5 & 12.1 \\
\hline T. whiteheadi & - & - & 3.1 & 3.5 & 0.3 & - & 6.1 & 6.0 & 11.4 & 37.7 & 24.0 & 18.3 & 11.3 \\
\hline P. bindus & - & - & - & - & 0.3 & - & 1.5 & - & 1.4 & 9.4 & 26.3 & 42.7 & 10.4 \\
\hline O. niloticus & 14.5 & 0.9 & 20.9 & 6.2 & 21.5 & - & 1.5 & 1.5 & 21.4 & 3.3 & 4.3 & 6.6 & 10.2 \\
\hline C. zillii & 25.4 & & 1.2 & 1.4 & 11.6 & - & 54.5 & 44.8 & 5.7 & 3.7 & 1.3 & 1.5 & 9.48 \\
\hline P. subviridis & - & - & 5.5 & 19.3 & 5.0 & 1.5 & 9.1 & 10.4 & 11.4 & 11.1 & 0.3 & 2.2 & 5.18 \\
\hline T. vitriastris & - & - & 0.6 & & 0.3 & 1.5 & - & - & 8.6 & 7.4 & 11.7 & 8.4 & 3.97 \\
\hline T. ilisha & 1.8 & 12.8 & 9.8 & 4.8 & 3.0 & 16.9 & 6.1 & 7.5 & & 0.8 & 1.7 & 0.4 & 3.78 \\
\hline B. fuscus & - & - & - & - & 0.3 & - & 1.5 & 3.0 & 2.9 & 5.7 & 5.4 & 0.4 & 1.73 \\
\hline
\end{tabular}

The values of Bray-Curtis similarity index of fish species between the two sites were high during the period of low salinity in both sites (Fig. 6), reaching to maximum value (97.14\%) in May. While, the lowest value of similarity index $(55.17 \%)$ was recorded in July, corresponding with the increase in the salinity in both sites. 


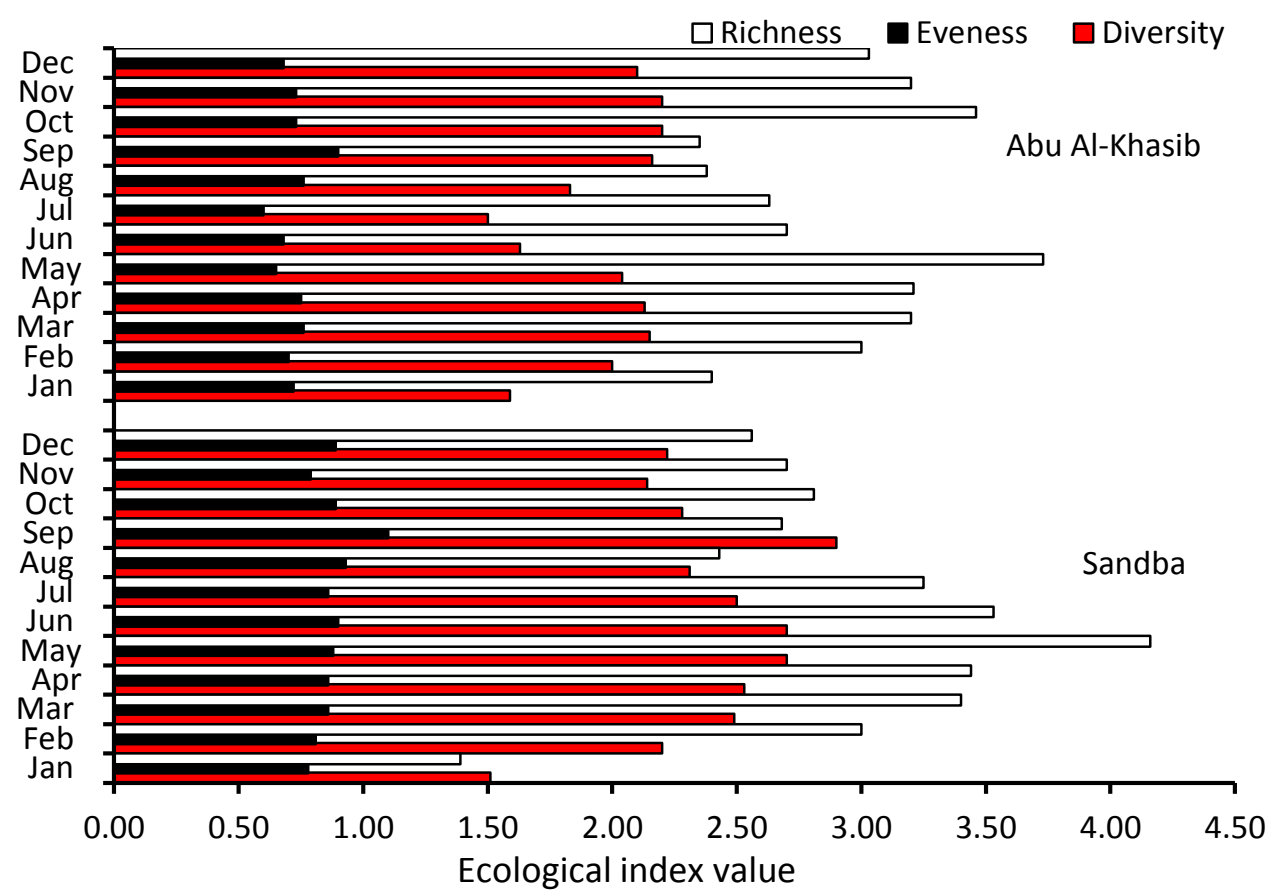

Figure 5: Monthly variations in the ecological indices values in both sites

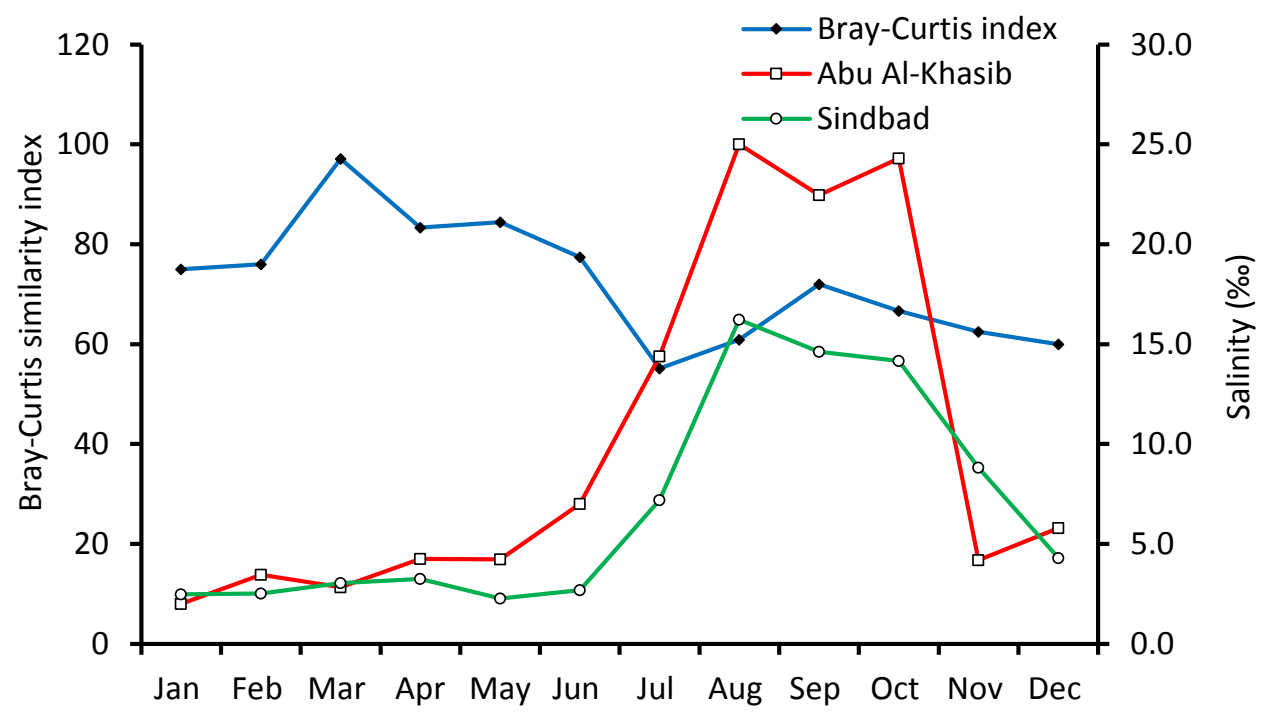

Figure 6: Monthly variations in the values of Bray-Crurtis index and salinity in both sites

\section{DISCUSSION}

One of the main finding of this study is the high level of salinity in the Shatt al-Arab river compared to previous years, due to the salinity intrusion caused by the reduction in water discharge to the river at the beginning of 2018, beside the diversion of the Karun River across Iranian territory, which was an important source of fresh water entering the Shatt AlArab, has reduced the ability of the river to act as natural barrier to the intrusion of the salt wedge from the Arabian Gulf. [37] mentioned that the Shatt Al-Arab river exposed to the salinity intrusion from the Arabian Gulf by molecular diffusion, where the salinity intermission the distance about $100 \mathrm{~km}$ for a period between three to four months, this condition is due to the decreasing of the water discharge from the upstream of the river. [38] stated that for rivers that flow directly into the sea, lower freshwater inflow results in saltwater intrusion that may extend several kilometres upstream into non-tidal reaches.

The time series analysis of freshwater discharges to the Shatt Al-Arab river from 2014 to 2018 showed that the first months of 2018 showed a clear decline in freshwater flow into the river as compared to previous years (Fig. 7), thereby 
allowing the saltwater wedge to move further and further upstream in the following months, and salinity level persisted rising substantially despite the large amount of the freshwater flow from upstream later, and this may be due to this inflows are not sufficient enough to push accumulated salt wedge toward south, as a result of low slope of the river towards the Gulf and the rise of the Arabian Gulf water level due to natural causes [18, 3] and this took time to reduce the salinity intrusion in the river, makes the river water unfit for human consumption and unacceptable for irrigation practices.

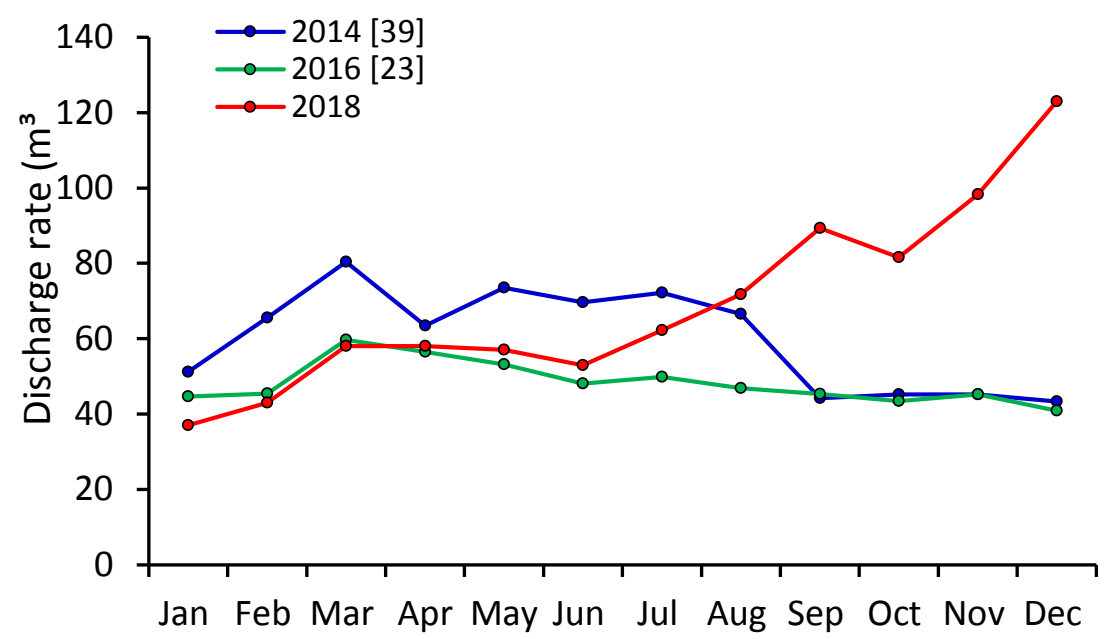

Figure 7: Monthly rate of discharge in the upstream of the Shatt Al-Arab River from 2014 to 2018

However, these salinity values were considerably higher than previous records. For instance, [40] mentioned that the salinity of the river at Sindbad was 1.5-2.7\% during 1992-1993, whereas the salinity ranged from 0.96 to $5.00 \%$ at the same site during 2007-2008 [41]. [42] stated that the salinity of Shatt Al-Arab River at Abu Al-Khasib ranged from 0.7 to 1.4\%o during 1997-1998. The salinity of the river at Abu Al-Khasib was 1.4-3.8\%o during 2010-2011[21]. [43] found that the salinity values of the river at Sindbad and Abu Al-Khasib were 1.5-8.1\%o and 1.0-16.7\%o, respectively during 20092010. [22] stated that the salinity of Shatt Al-Arab river at Sindbad and Abu Al-Khasib ranged from 1.09 to 2.27\%o and 1.4 to $6.19 \%$, respectively during 2011-2012. However, the values of 1.6-4.6\%o were recorded at Abu-Khasib site during 20152016 [44]. However, [7] reported that the main factors affecting salinity intrusion in the Valapattanam River, India are river topography, the sea level variation, decrease in upstream runoff, increase in temperature, decrease in precipitation. The impact of low water discharge in the Shatt Al-Arab River and the saltwater intrusion further upstream is well documented by several authors [17, 43, 3, 20].

Other main findings of present study are the high percentage of marine species and the equally in the proportions of native and exotic species in each of studied sites, this is a new happening compared to previous studies on this part of the Shatt Al-Arab river. The marine, native and exotic species in Sindbad constituted 52.9, 23.5 and 23.5\%, respectively, and in Abu Al-Khasib were 63.6, 18.2 and 18.2\%, respectively. [40] stated that the ratios of marine, native and exotic species in Sindbad were 28.6, 61.9 and 9.5\%, respectively during 1992-1993, whereas the proportions of these species in Abu AlKhasib during 2010-2011 were 52.2, 30.4 and 17.4\%, respectively [21]. [22] mentioned that the percentage of the marine, native and exotic species in Sindbad were 40.0, 37.1 and 22.9\%, respectively, and in Abu Al-Khasib were 60.4, 24.5 and $15.1 \%$, respectively during 2011-2012. [44] found that the ratios of these species Abu-Khasib site during 2015-2016 were $56.9,21.6$ and $21.6 \%$, respectively. These variations in the ratios of the species may be due to increase in the salinity of the river, as environmental conditions change, some fish species migrate in response to variation in salinity and moving up and down the estuary $[45,46]$.

The most abundant species in Sindbad were P. latipinna, T .ilisha and O. aureus, whereas O. aureus, C. auratus and P. latipinna in Abu Al-Khasib. It is clear that the exotic species dominated the fish community in the middle part of the river, except in Sindbad, where the migratory species, $T$.ilisha occupied the second position, because this species exploit this site for spawning every year $[42,47]$. These results were contrasted with the findings reported earlier about the fish assemblage in this part of the river. [40] stated that the most abundant species in Sindbad were A. marmid (51.8\%), A. dispar (18.8\%) and P. abu (9.5\%) during 1992-1993, whereas C. auratus (25.9\%), L. klunzingeri (22\%) and C. zilli (11\%) during 2011-2012 [22]. [21] Mohamed, et al. (2012a) found that the dominated species in Abu Al-Khasib were C. auratus (37.3\%), T. ilisha (19.4\%) and P. subviridis (7.7\%) during 2010-2011, while [22] revealed that C. auratus, T. ilisha and P. klunzingeri were dominated the fish assemblage in this site during 2011-2012, constituted 46.1, 21.6 and 5.4\%, respectively. [44] found that the most abundant species in Abu Al-Khasib were C. auratus (19.7\%), O. aureus (19.3\%) and C. zilli (12.4\%) during 2015-2016. 
Further, during the present study fish diversity indices i.e. diversity, richness and evenness revealed that values were 2.37, 2.95 and 0.88, respectively in Sindbad, and 1.96, 2.94 and 0.72, respectively in Abu Al-Khasib. Present findings are in line with other workers who also observed seasonal changes in the fish diversity indices in this part of Shatt Al-Arab river $[47,22,44]$. The richness index has a general tendency to show high values during spring months and reached to highest values during May in both sites which could be attributed largely to the penetration of marine migratory species, such as T. ilisha, T. whiteheadi, T. vitriastris P. Subviridis and P. bindus to reproduction or nursery or feeding, or migration route corresponding with increased in salinity. This result is supported by the high percentage of the occasional species which constituted 50\% of the total number of species in Sindbad and 75\% of species in Abu Al-Khasib. The effects of decreasing river flow and salinity intrusion on the fish assemblages have been observed by different authors around the world $[11,48,49,38,50]$.

Finally, the findings of the present study indicate that the salinity values and the percentages of marine and occasional species were considerably higher than that documented in the previous studies on this part of the river.

\section{REFERENCES}

[1] Prandle D. "Estuaries: Dynamics, Mixing, sedimentation and Morphology". Cambridge University Press, N.Y., 2009.

[2] Montanari A. "Saltwater intrusion". (https://distart119.ing.unibo.it/albertonew/?q= node/152). University of Bologna. Online version, updated 18 April 2017. 2015

[3] Yaseen BR, Al-Asaady KA, Kazem AA, Chaichan MT. "Environmental Impacts of Salt Tide in Shatt Al-ArabBasra/Iraq", Journal of Environmental Science, Toxicology and Food Technology, vol 10, pp. 35-43, 2016.

[4] Sierra JP, Sanchez-Arcila A, Figueras PA, Gonzalez del Rio, J, Rassmussen EK, Mösso C. "Effects of discharge reductions on salt-wedge dynamics of the Ebro River". River Res. Appl. vol 20, pp, 61-77, 2014,

[5] Zhang Z, Cui B, Zhao H, Fan X, Zhang H. "Discharge-salinity relationships in Modaomen waterway, Pearl River estuary". Procedia Environmental Sciences, vol 2, pp. 1235-1245, 2010.

[6] Watanabe K, Kasai A, Antonio ES, Suzuki K, Ueno M, Yamashita Y. "Influence of salt-wedge intrusion on ecological processes at lower trophic levels in the Yura Estuary, Japan". Estuarine, Coastal and Shelf Science, vol 139, pp. 67-77, 2014.

[7] Arun Raj NA, Vasudeo AD. "Salinity Intrusion in Valapattanam River, Kerala". International Journal of Engineering Research \& Technology, vol 4(11), pp. 710-713, 2015.

[8] Haddout S, Maslouhi A, Igouzal M. "Predicting of salt water intrusion in the Sebou river estuary (Morocco)". Journal of Applied Water Engineering and Research, vol 5(1), pp. 40-50, 2017.

[9] Xu Z, Ma J, Wang H, Hu Y, Yang G, Wei Deng W. "River Discharge and Saltwater Intrusion Level Study of Yangtze River Estuary, China", Water, vol 10 pp. 1-22, 2018.

[10] Martino EJ, Able KW. "Fish assemblages across the marine to low salinity transition zone of a temperate estuary", Estuarine, Coastal and Shelf Science, vol 56, pp. 969-987, 2003.

[11] Love JW, Gill J, Joshua J, Newhard JJ. "Saltwater Intrusion Impacts Fish Diversity And Distribution In The Blackwater River Drainage (Chesapeake Bay Watershed)", Wetlands, vol 28, pp. 967-974, 2008.

[12] Jutagate T, Sawusdee A, Chaidee T, Thapanand-Chaidee T, Lek S, Grenouillet G, Thongkhoa S, Chotipuntu P. "Effects of an anti-salt intrusion dam on tropical fish assemblages", Marine and Freshwater Research, vol 61, pp. 288$301,2010$.

[13] Romañach SS, Beerens JM, Patton BA, Chapman JP, Hanson MR. "Impacts of Saltwater Intrusion on Wetland Prey Production and Composition in a Historically Freshwater Marsh", Estuaries and Coasts, vol 42 pp. 1-12, 2019.

[14] Partow H. "The Mesopotamian Marshlands: Demise of an Ecosystem. Early Warning and Assessment", Technical Report, UNEP/DEWA/TR.01-3 Rev. 1, 2001.

[15] Al-Mahmood HKH, Hassan WF, Alhello AZA, Hammood AI, Muhson NK. "Impact of low discharge and drought of the water quality of the Shatt Al-Arab and Al-Basrah Rivers (south of Iraq)", Journal of International Academic Research Multidisciplinary, vol 3, pp. 285-296. 2015.

[16] Hameed AH, Aljorany YS. "Investigation on nutrient behavior along Shatt Al-Arab River River, Basrah, Iraq", J. Appl. Sci. Res., vol 7, pp. 1340-1345. 2011.

[17] Al-Tawash B, Al-Lafta HS, Merkel B. "Preliminary Assessment of Shatt Al-Arab Riverine Environment, Basra Governorate, Southern Iraq", Journal of Natural Science Research, vol 3, pp. 120-136, 2013.

[18] Hameed HA, Ali MH, Aljorany YS, Hassan WF, Al-Hello AAZ. "Assessing changes in seawater intrusion and water quality of the Shatt Al-Arab River, Iraq". Ann. Limnol. Int. J. Lim., vol 49, pp. 199-206, 2013.

[19] Moyel MS, Hussain NA. "Water quality assessment of the Shatt al-Arab River, Southern Iraq", Journal of Coastal Life Medicine, vol 3, pp. 459-465, 2015.

[20] Abdullah AD, Karim UFA, Masih I, Popescu I, Zaag PV. "Anthropogenic and tidal influences on salinity levels of the Shatt al-Arab River, Basra, Iraq", International Journal of River Basin Management, vol 14, pp. 357-366, 2016. 
[21] Mohamed ARM, Resen AK, Tahe MM. "Longitudinal patterns of fish community structure in the Shatt Al-Arab River, Iraq", Basrah J. Sci. vol 30, pp. 65-86, 2012.

[22] Mohamed ARM, Hussein SA, Lazem LF. "Spatiotemporal variability of fish assemblage in the Shatt Al-Arab River, Iraq", Journal of Coastal Life Medicine, vol 3(1), pp. 27-34, 2015.

[23] Mohamed ARM, Abood AN. "Compositional change in fish assemblage structure in the Shatt Al-Arab River, Iraq. Asian Journal of Applied Sciences, vol 5, pp. 944-958, 2017.

[24] Yaseen AT. "The impact of certain environmental factors on the nature of the fish assemblage in the Shatt Al-Arab river". MSc. thesis, Faculty of Agriculture, Tikrit University, 2016.

[25] Al-Lami ORT. "Some Marine Properties for Arabian Gulf on North Part's Hydrology of Shatt Al Arab Riverbed". MSc thesis. Basrah University, Basrah, Iraq, 2009.

[26] Abdullah AA, Issa M, Saleh AQJ, Qassim A. "Physical and chemical properties of water for the northern part of the Shatt Al-Arab River", Basra J. Agriculture Sciences, vol 14, pp. 123-42, 2001.

[27] Carpenter KE, Krupp F, Jones DA, Zajonz U. "FAO species identification field guide for fishery purposes. Living marine resources of Kuwait, Eastern Saudi Arabia, Bahrain, Qatar and the United Arab Emirates", FAO, Rome. 293 p., 1997.

[28] Coad WB. "Freshwater Fishes of Iraq", www.briancoad.com, 2017.

[29] Eschmeyer WN. "Catalog of Fishes: species by family/subfamily", (http:// researcharchive. calacademy.org/research/ichthyology/catalog/SpeciesByFamily.as). Online version, updated 28 April 2017.

[30] Froese R, Pauly D. "In FishBase. World Wide Web electronic publication", www.fishbase.org, version (10/2017). [31] Odum, W.A. 1970. Insidious alternation of the estuarine environment. Trans. Am. Fish. Soc. 99, 836-847.

[31] Odum WA. "Insidious alternation of the estuarine environment", Trans. Am. Fish. Soc., vol 99, pp. 836-847, 1970.

[32] Shanon CE, Weaver W. "The mathematical theory of communication", University of Illionis. Press Urbane, 1963.

[33] Margalef R. "Perspectives in ecology", University of Chicago Press, 1968.

[34] Pielou EC. "Mathematical ecology", John Wiely, New York, 1977.

[35] Bray JR, Curtis JT. "An ordination of upland forest communities of southern Wisconsin", Ecological Monographs, vol 27, pp. 325-349, 1957.

[36] Tyler AV. "Periodic and resident components in communities of Atlantic fishes", J. Fish. Res. Bd. Can., vol 28(7), pp. 935-946, 1971.

[37] Al-Taei SA, Abdulla SS, A. A. Lafta AA. "Longitudinal intrusion pattern of salinity in Shatt Al Arab estuary and reasons" KAU: Mar. Sci., vol 25, pp. 205-221, 2014.

[38] Pizano-Torres RI, Roach KA, Winemiller KO. "Response of the fish assemblage to a saltwater barrier and paper mill effluent in the Lower Neches River (Texas) during drought" Journal of Freshwater Ecology, vol 32, pp. 147-162, 2017.

[39] Alaidani MAT. "The change in the geographic and agricultural properties impacts in the province of Basra", MSc. Thesis, University of Basra, College of Education Sciences, 2014.

[40] Hussain NA, Younis KH, Yousif UH. "The influence of low salinity temperature and domestic sewage of the distribution of fish assemblage in the Shatt Al-Arab River, Iraq" Marina Mespotamica, vol 10, pp. 257-274, 1995..

[41] Hammadi NS, Salman DS, Al-Essa SA. "Diversity of Rotifera in the Shatt Al-Arab Region, Southern of Iraq", Journal of Fisheriessciences.com, vol 10, pp. 12-26. 2016.

[42] Al-Mahdi AA, Hussain NA, Al-Noor SS. "Survey of ichthyoplankton from northern part of Shatt Al-Arab River", Marina Mesopotamica, vol 15, pp. 571-380, 2000.

[43] Hameed HA, Ali MH, Aljorany YS, Hassan WP, Al-Hello AAZ. "Assessing changes in seawater intrusion and water quality of the Shatt Al-Arab River, Iraq", Ann. Limnol. Int. J. Lim., vol 49, pp. 199-206, 2013.

[44] Abood AN. "Study of structure and distribution of fish assemblages in the Shatt Al- Arab River", Ph.D. thesis, University of Basrah, Iraq, 2018.

[45] Blaber SJ, Blaber TG. "Factors affecting the distribution of juvenile estuarine and inshore fish", J. Fish Biol. Vol 17, pp. 143-162, 1980.

[46] Barletta M, Barletta-Bergan A, Saint-Paul U, Hubold G. "Seasonal changes in density, biomass, and diversity of estuarine fishes in tidal mangrove creeks of the lower Caete Estuary (northern Brazilian coast, east Amazon)", Mar. Ecol. Prog. Ser., vol 256, pp. 217-228, 2003.

[47] Mohamed ARM, Ahmed SM, Al-Okailee MT. "Variations in occurrence, abundance and diet of hilsa, Tenualosa ilisha larvae in the north of Shatt Al-Arab River, Iraq" Basrah Journal of Agriculture Science, vol 25, pp. 40-52, 2012.

[48] Xinfeng Z, Jiaquan D. "Affecting Factors of Salinity Intrusion in Pearl River Estuary and Sustainable Utilization of Water Resources in Pearl River Delta". In; Fukushi K, Hassan K M, Hondar R, Sumi A. (eds.). Sustainability in Food and Water: An Asian Perspective. p. 11-17, 2010.

[49] de Melo GV, Neto SJAB, Vinz'on UB, de Oliveira AS, Vicente MAF, Malm O, da Silva CG. "Salinity intrusion in the Guapimirim Estuary, Rio de Janeiro, Brazil", Revista Brasileira de Geof'1sica, vol 32(1), pp. 1-16, 2014,2014

[50] Engman AC, Kwak TJ, Fischer JR, Lilyestrom CG. "Fish Assemblages and Fisheries Resources in Puerto Rico's Riverine Estuaries", Marine and Coastal Fisheries, vol 11, pp. 189-201, 2019. 